\title{
Structural and functional diversity of free-living microorganisms in reef surface, Kra island, Thailand
}

Naraporn Somboonna ${ }^{1 *}$, Alisa Wilantho², Anunchai Assawamakin³, Somchai Monanunsap ${ }^{4}$, Duangjai Sangsrakru², Sithichoke Tangphatsornruang ${ }^{2}$ and Sissades Tongsima ${ }^{2^{*}}$

\begin{abstract}
Background: Coral reefs worldwide are being harmed through anthropogenic activities. Some coral reefs in Thailand remain well-preserved, including the shallow coral reefs along Kra island, Nakhon Si Thammarat province. Interestingly, the microbial community in this environment remains unknown. The present study identified biodiversity of prokaryotes and eukaryotes of $0.22-30 \mu \mathrm{m}$ in sizes and their metabolic potentials in this coral reef surface in summer and winter seasons, using $16 \mathrm{~S}$ and $18 \mathrm{~S}$ rRNA genes pyrosequencing.

Results: The marine microbial profiles in summer and winter seasons comprised mainly of bacteria, in phylum, particular the Proteobacteria. Yet, different bacterial and eukaryotic structures existed between summer and winter seasons, supported by low Lennon and Yue \& Clayton theta similarity indices (8.48-10.43\% for 16S rRNA, 0.32-7.81\% for $18 \mathrm{~S}$ rRNA ). The topmost prokaryotic phylum for the summer was Proteobacteria (99.68\%), while for the winter Proteobacteria (62.49\%) and Bacteroidetes (35.88\%) were the most prevalent. Uncultured bacteria in phyla Cyanobacteria, Planctomycetes, SAR406 and SBR1093 were absent in the summer. For eukaryotic profiles, species belonging to animals predominated in the summer, correlating with high animal activities in the summer, whereas dormancy and sporulation predominated in the winter. For the winter, eukaryotic plant species predominated and several diverse species were detected. Moreover, comparison of our prokaryotic databases in summer and winter of Kra reef surface against worldwide marine culture-independent prokaryotic databases indicated our databases to most resemblance those of coastal Sichang island, Chonburi province, Thailand, and the 3 tropical GOS sites close to Galapagos island (GS039, GS040 and GS045), in orderly.
\end{abstract}

Conclusions: The study investigated and obtained culture-independent databases for marine prokaryotes and eukaryotes in summer and winter seasons of Kra reef surface. The data helped understand seasonal dynamics of microbial structures and metabolic potentials of this tropical ecosystem, supporting the knowledge of the world marine microbial biodiversity.

Keywords: Biodiversity, Prokaryote, Eukaryote, 16S ribosomal RNA, 185 ribosomal RNA, Reef surface, Pyrosequencing

\footnotetext{
*Correspondence: Naraporn.S@chula.ac.th; sissades@biotec.or.th

'Department of Microbiology, Faculty of Science, Chulalongkorn University,

Bangkok 10330, Thailand

${ }^{2}$ Genome Institute, National Center for Genetic Engineering and

Biotechnology, Khlong Nueng, Khlong Luang, Pathum thani 12120, Thailand

Full list of author information is available at the end of the article
} 


\section{Background}

Previous studies reported different species and species distribution patterns in different coastal and open ocean environments, climates, distances from seashores, and sea depths [1-4]. Dinsdale and colleagues [5] described different prokaryotic and viral communities across 4 coral atolls of the Northern Line Islands, influenced by oceanographic conditions and human activities associated with land-use and fishing. Human activities are considered a major factor driving microbial structure changes $[4,6-8]$. Somboonna et al. [4] reported that two opposite coastal niches of the non-vast Sichang island with different degrees of manmade pollutions contained diverse microbial structures. Furthermore, seasonal variation affects the microbial diversity. Studies described the repeatable seasonal dynamic of the microbial structures in temperate coastal water of N50.2518 W4.2089 with peak biodiversity in the winter season $[9,10]$. Yet, the seasonal dynamic of the microbial structure of the tropical coral reef remains unrevealed.

Coral reefs of tropical waters between $30^{\circ} \mathrm{N}$ and $30^{\circ} \mathrm{S}$ are generally around shallow depth. This shallow-water reef zone, known as reef surface, is affected by the surge of water tides that further enhances the biodiversity. Although coral reefs cover less than 1\% of the Earth's surface, they are home to approximately $25 \%$ of marine fish species [11-14]. Corals, coral animals and microbiota have intricate relationship. For instances, coral animals and microbiota could protect the corals from water temperature rise, pollution, and also from specific pathogens by filling entry niches and/or producing antibiotics $[5,15,16]$. Changing of microbial associates could help the coral animals adapt to altering coral niches $[15,17]$. In contrast, coral bleaching causes change to the microbial community balance [18]. Thus, it is of importance to understand these dramatically fruitful marine microbial communities.

Currently, culture-independent method has been in widespread use to obtain microbial databases for marine and other various environmental resources $[1,11,13]$. This derived the global ocean sampling exploration (GOS) project that was launched in 2003 by JC Venter to gain understanding of microbial diversity for entire marine environments, including coastal water, open ocean, seafloor and seawater at different depths [1,3,4,19-21]. While no study for culture-independent microbial diversity of any coral reef environment in Thai maritime has been established, this study represents the first to use $16 \mathrm{~S}$ and 18S rRNA pyrosequencing with metagenomic DNA to identify the summer and winter microbial structures and their metabolic potentials representing Thailand's tropical reef surface of Kra island, helping to understand our global marine biodiversity.

Being situated just above the equator makes Thailand a tropical climate with great biodiversity of microbes and organisms. Kra island, or Ko Kra, is located in the Gulf of Thailand at N8.39817 E100.73283, about 437 miles $(700 \mathrm{~km})$ south of Bangkok and 34 miles $(54 \mathrm{~km})$ east of Nakhon Si Thammarat province of Thailand (Figure 1). The coral reefs around Kra island are still in well-preserved condition due to the minimal anthropogenic impact, meanwhile the world's coral reefs have been dramatically degraded in the past few decades [14]. Kra island is uninhabited as it has a small size of less than 0.1 square miles and is remote from the mainland.

\section{Results}

\section{General characteristics of Kra reef surface}

Three independent water samples representing Kra island reef surface were collected at N8.40116 E100.73232, N8.39768 E100.73643 and N8.36135 E100.73524, during midday in summer (May 2011) and winter (January 2012) seasons of Thailand. All collected water samples were clean and had no abnormal smell. On-site physical and chemical property measurements of the collected water samples expressed similar $\mathrm{pH}$, salinity and temperature between the two seasons, while dissolved oxygen was higher and suspension solids were fewer in the winter (Table 1).

Following a two-step water filtration system to capture marine microbes or particles of 0.22-30 microns in diameters $[4,22]$ and total nucleic acids extraction, the average metagenomic DNA retrieved for the summer and the winter samples were 0.22 and 0.19 nanogram per millilitre of seawater, respectively.

\section{Species compositions at domain and taxon levels}

Libraries of summer and winter $16 \mathrm{~S}$ and $18 \mathrm{~S}$ rRNA genes sequences were successfully constructed and sequenced: 66,600 total reads were classified into 14,189 reads for summer $16 \mathrm{~S}$ rRNAs, 42,659 for winter $16 \mathrm{~S}$ rRNAs, 1,709 for summer $18 \mathrm{~S}$ rRNAs, and 8,043 for winter $18 \mathrm{~S}$ rRNAs. The average number of reliable reads (having read length of greater than or equal to 50 nucleotides) was $97.43 \%$ and the average read length was 186 nucleotides. $96.23 \%$ of the reliable reads could be identified by BLASTN against NCBI [23], RDP [1,24] and Greengenes [25] for 16S rRNA genes; and NCBI [23], EMBL [26,27] and SILVA [28] for 18S rRNA genes. Similarly, analysis by mg-RAST (metagenomics - Rapid Annotation using Subsystems Technology) $[29,30]$ revealed high numbers of reliable reads: $95.9 \%$ for summer and $99.2 \%$ for winter.

Comparing between Bacteria and Eukarya domains using mg-RAST, Bacteria domain was more present than Eukarya in both seasons, although the great proportion of Eukaryota was found in the winter (Figure 2). Different taxonomic compositions between the seasons were demonstrated: summer mainly comprised taxons Proteobacteria, unclassified (derived from bacteria), Actinobacteria, Firmicutes, Mullusca, Cyanobacteria, Arthopoda, Nematoda, 


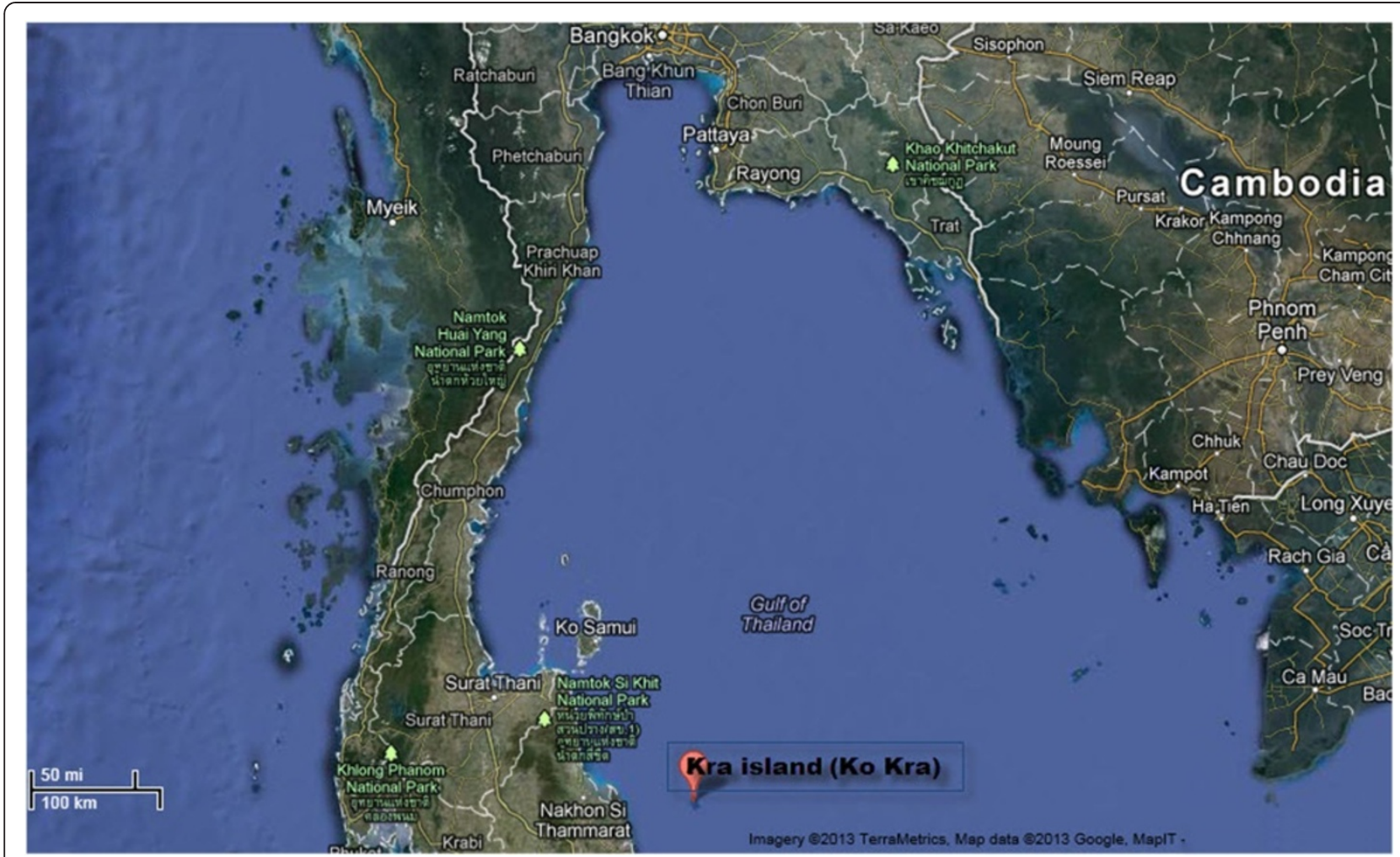

Figure 1 Satellite map of Kra island. The map was from Google Satellite Map, retrieved on 7 May 2013, from http://maps.google.com/. Red represents Kra island.

Brachiopoda, and Annelida, in orderly. The winter mainly comprised of taxons Proteobacteria, Bacteroidetes, Actinobacteria, unclassified (derived from eukaryotes), Arthropoda, unclassified (derived from bacteria), Chordata, Firmicutes, and Apicomplexa (Figure 3).

It is important to note that the varied pyrosequencing depths between summer and winter $16 \mathrm{~S}$ and $18 \mathrm{~S}$ rRNA datasets were normalized by random selection of equal number of reads from both summer and winter seasons for comparative analysis of microbial communities. 10,000 random reads of each $16 \mathrm{~S}$ and 1,600 reads of each $18 \mathrm{~S}$ rRNA datasets were examined for distributions by taxons (Additional file 1: Figure S1) and phyla (Additional file 2: Table S1). These distribution patterns were similar to those computed using the entire datasets (Figure 3 and Table 2). The normalization analyses were independently performed twice, and the results remained the same. Additionally, rarefaction cures of the number of phyla on the Y-axis against the number of random reads on the $\mathrm{X}$-axis were

Table 1 General water properties

\begin{tabular}{llllll}
\hline Seasons & $\mathbf{p H}$ & $\begin{array}{l}\text { Salinity } \\
(\mathbf{p p t})\end{array}$ & $\begin{array}{l}\text { Temperature } \\
\left({ }^{\circ} \mathbf{C}\right)\end{array}$ & $\begin{array}{l}\text { Dissolved } \\
\text { oxygen }(\mathbf{m g} / \mathbf{L})\end{array}$ & $\begin{array}{l}\text { Suspension } \\
\text { solids }(\mathbf{m g} / \mathbf{L})\end{array}$ \\
\hline Summer & 7.5 & 31.7 & 30.2 & 6.3 & 13.1 \\
Winter & 7.5 & 32.0 & 29.1 & 7.0 & 11.9 \\
\hline
\end{tabular}

constructed for $16 \mathrm{~S}$ and $18 \mathrm{~S}$ rRNA datasets, and the plateau curves showing relatively no new phyla at these sequencing depths were observed for the $16 \mathrm{~S}$ and $18 \mathrm{~S}$ rRNA data.

Prokaryotic diversity of summer and winter Kra reef surface As an additional analysis to the mg-RAST analysis for domain and taxon compositions, the 16S rRNA sequence profiles of summer and winter Kra prokaryotes were species annotated by BLASTN [31] with E-value threshold $\leq 10^{-5}$ against NCBI non-redundant [23], RDP [24] and Greengenes [25] databases. With added databases, most unclassified (derived from Bacteria) by mg-RAST analysis became annotated. The summer profile demonstrated an overwhelming proportion of Proteobacteria $(99.68 \%)$, whereas the winter profile constituted the higher phyla diversity: Proteobacteria $(62.49 \%)$, Bacteroidetes (35.88\%), and the greater proportion of Actinobacteria (8.95-fold) and Firmicutes (4.73-fold) than those in the summer (Table 2A). Prokaryotic phyla, including Cyanobacteria, SAR406, Planctomycetes and SBR1093, were only detected in the winter (Table 2A). SAR406 (from Greengenes database) represents uncultured bacteria that were previously discovered in Atlantic and Pacific oceans. Its full-length $16 \mathrm{~S}$ rRNA phylogeny was not clustered with any bacterial phyla except was 


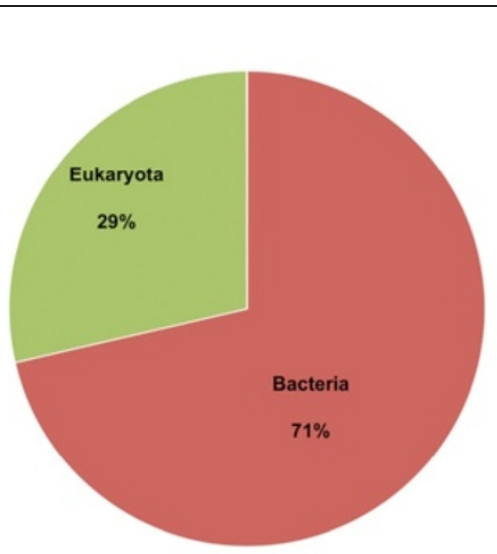

Summer

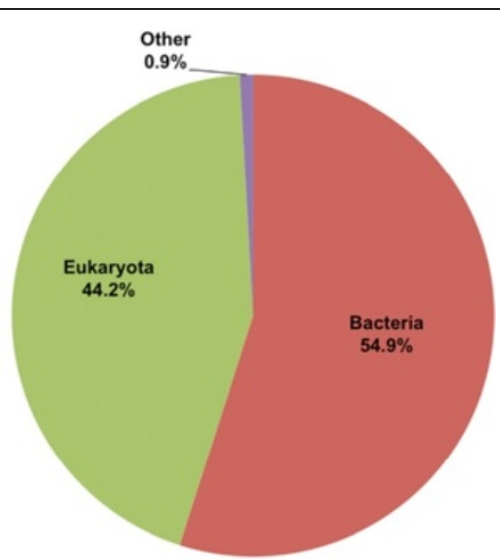

Winter

Figure $216 \mathrm{~S}$ and 18S rRNA genes overview for domain compositions. "Other" denotes species not belong to Bacteria and Eukarya domains by mg-RAST.

a distant relative to genera Fibrobacter (the only genus of phylum Fibrobacteres, capable of degrading plant fiber) and Chlorobium (green sulfur bacteria of phylum Chlorobi) [32]. SBR1093 (a relative of green sulfur bacteria Chlorobium in Chlorobi; from Greengenes database) represents uncultured bacteria which previous research found in wastewater treatment plants with biological nutrient removal [33].

Within the same phyla, the summer and winter Kra reef surface prokaryotic communities showed further characteristic species compositions as determined by low community structure relatedness Lennon (10.43\%) and Yue \& Clayton $(8.48 \%)$ theta similarity indices. Species predominated in the summer were uncultured Proteobacteria sp., Erwinia sp., Nautella italica, Vibrio sp. and Vibrio splendidus; meanwhile species predominated in the winter were Pectobacterium carotovorum, Pseudoalteromonas sp., marine bacterium, Sulfitobacter sp., Croceibacter atlanticus and Flavobacteria bacterium
(Figure 4). Marine bacterium represents one taxon name in Greengenes database, including isolates VS05_121 (from South Pacific), B36 (North sea of the United Kingdom) and KS-9-10-4 (South Korea), for instances.

\section{Eukaryotic diversity of summer and winter Kra reef surface}

As an additional analysis to the mg-RAST, the $18 \mathrm{~S}$ rRNA sequence profiles of summer and winter Kra prokaryotes were also species annotated by BLASTN [31] with E-value $\leq 10^{-5}$ against NCBI non-redundant [23], EMBL [26,27] and SILVA [28] databases and many additional unclassified (derived from Eukaryota) by mg-RAST were defined. Table 2B demonstrated the fewer eukaryotic phyla diversity in the summer than in the winter.

While fungal phyla were not abundant and thus did not demonstrate much difference, the compositional structures of the protist, plant and animal phyla were greatly different between the seasons (Table 2B). Overall,

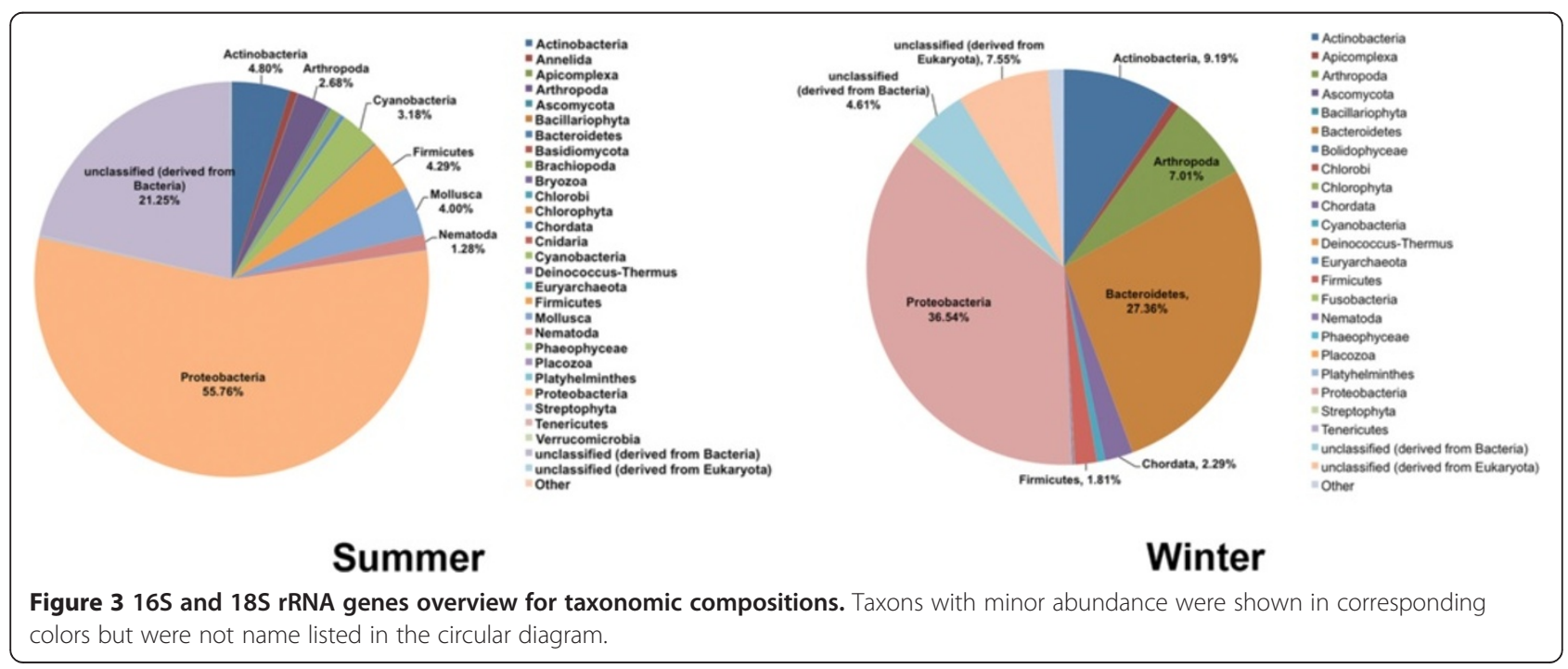


Table 2 Percent compositions of free-living prokaryotic (A) and eukaryotic (B) phyla in summer and winter seasons

\begin{tabular}{|c|c|c|}
\hline \multicolumn{3}{|l|}{$A$} \\
\hline Phyla & Summer (\%) & Winter (\%) \\
\hline Proteobacteria & 99.681 & 62.950 \\
\hline Actinobacteria & 0.082 & 0.739 \\
\hline Bacteroidetes & 0.208 & 36.146 \\
\hline Firmicutes & 0.030 & 0.143 \\
\hline SAR406 & - & 0.005 \\
\hline Planctomycetes & - & 0.005 \\
\hline Cyanobacteria & - & 0.010 \\
\hline SBR1093 & - & 0.002 \\
\hline \multicolumn{3}{|l|}{ B } \\
\hline Phyla (Kingdom) & Summer (\%) & Winter (\%) \\
\hline Ascomycota (Fungi) & 0.924 & 1.534 \\
\hline Basidiomycota (Fungi) & 0.231 & 0.039 \\
\hline Glomeromycota (Fungi) & 0.115 & - \\
\hline Neocallimastigomycota (Fungi) & - & 0.052 \\
\hline Zygomycota (Fungi) & - & 0.039 \\
\hline Apicomplexa (Protist) & - & 1.403 \\
\hline Ciliophora (Protist) & - & 1.062 \\
\hline Dinophyta (Protist) & 10.855 & 0.354 \\
\hline Mycetozoa (Protist) & - & 0.184 \\
\hline Bacillariophyta (Plant) & 1.617 & 72.473 \\
\hline Chlorophyta (Plant) & 0.231 & 0.197 \\
\hline Cryptophyta (Plant) & 0.346 & 0.118 \\
\hline Eustigmatophyceae (Plant) & - & 0.013 \\
\hline Haptophyta (Plant) & - & 0.118 \\
\hline Phaeophyceae (Plant) & - & 0.354 \\
\hline Pinguiophyceae (Plant) & - & 0.262 \\
\hline Stramenopiles (Plant) & - & 14.825 \\
\hline Streptophyta (Plant) & 0.115 & 0.105 \\
\hline Xanthophyceae (Plant) & 0.115 & 0.669 \\
\hline Annelida (Animal) & 15.589 & 0.184 \\
\hline Arthropoda (Animal) & 6.236 & 0.079 \\
\hline Brachiopoda (Animal) & 37.067 & 0.013 \\
\hline Chordata (Animal) & 1.039 & 0.734 \\
\hline Cnidaria (Animal) & - & 0.459 \\
\hline Gastrotricha (Animal) & 0.231 & - \\
\hline Mollusca (Animal) & 23.672 & - \\
\hline Placozoa (Animal) & - & 4.706 \\
\hline Platyhelminthes (Animal) & 1.039 & 0.013 \\
\hline Porifera (Animal) & - & 0.013 \\
\hline Rotifera (Animal) & 0.557 & - \\
\hline
\end{tabular}

Each identified read was classified in its corresponding phylum. The proportional percentage of each phylum was calculated by dividing the number of the identified reads in a phylum with the total number of the identified reads. animals Brachiopoda, Mollusca and Annelida, and protists Dinophyta, constituted $87.12 \%$ of the total phyla compositions in the summer. On the other hand, plants Bacillariophyta and Stramenopiles constituted $87.30 \%$ of all phyla in the winter. Indeed, several plant phyla were missing in the summer (Table 2B).

Within the same phyla, the summer and winter Kra reef surface eukaryotic communities showed further characteristic species compositions as determined by low Lennon (7.81\%) and Yue \& Clayton $(0.32 \%)$ theta similarity indices. These similarity indices were even lower than those belonged the 16S rRNA profiles. Species predominated in the summer were Dinophysis acuminata (phylum Dinophyta, kingdom Protist), Myrina sp. (Arthropoda, Animal), Glycymeris pedunculata (Mollusca, Animal), Lingula anatina (Brachiopoda, Animal), Ctenodrilidae sp. (Annelida, Animal) and Hyotissa numisma (Mollusca, Animal). Species predominated in the winter were Nanofrustulum shiloi (Bacillariophyta, Plant), Climacosphenia moniligera (Bacillariophyta, Plant), Corethron criophilum (Bacillariophyta, Plant), Corethron hystrix (Bacillariophyta, Plant), Pirsonia diadema (Stramenophiles, Plant), and Trichoplax sp. (Placozoa, Animal), for examples (Figure 5).

\section{Metabolic subsystem analysis of bacterial communities in summer and winter Kra reef surface}

A total of 28 metabolic subsystems were found in summer and winter bacterial communities of Kra reef surface. Figure 6a demonstrated quite similarities in the distribution of these 28 subsystems between seasons, except in the subsystem of dormancy and sporulation that were more preponderated in the winter season. Overall, the main bacterial metabolic subsystems entailed carbohydrates, clustering-based subsystems, and amino acids and derivatives, respectively. Analysis of the distributions of functional groups within each subsystem showed that summer contained higher functional groups in: aromatic amino acids and derivatives (subsystem amino acids and derivatives); polysaccharides (carbohydrates); catabolism of an unknown compound, probably organic hydroperoxide resistance related hypothetical protein, probably Ybbk-related hypothetical membrane proteins, proteosome related, Shiga toxin cluster (clustering-based subsystems); coenzyme $\mathrm{M}$ (cofactors, vitamins, prosthetic groups, pigments); anaerobic degradation of aromatic compounds (metabolism of aromatic compounds); desiccation stress (stress response); invasion and intracellular resistance, toxins and superantigens (virulence, diseases and defense). For the winter the higher functional groups were: gram-positive cell wall components (cell wall and capsule); DNA metabolism, nucleotidyl-phosphate metabolic cluster, recombination related cluster, recX and regulatory cluster, related to Menaquinon-cytochrome $\mathrm{C}$ reductase, two related 

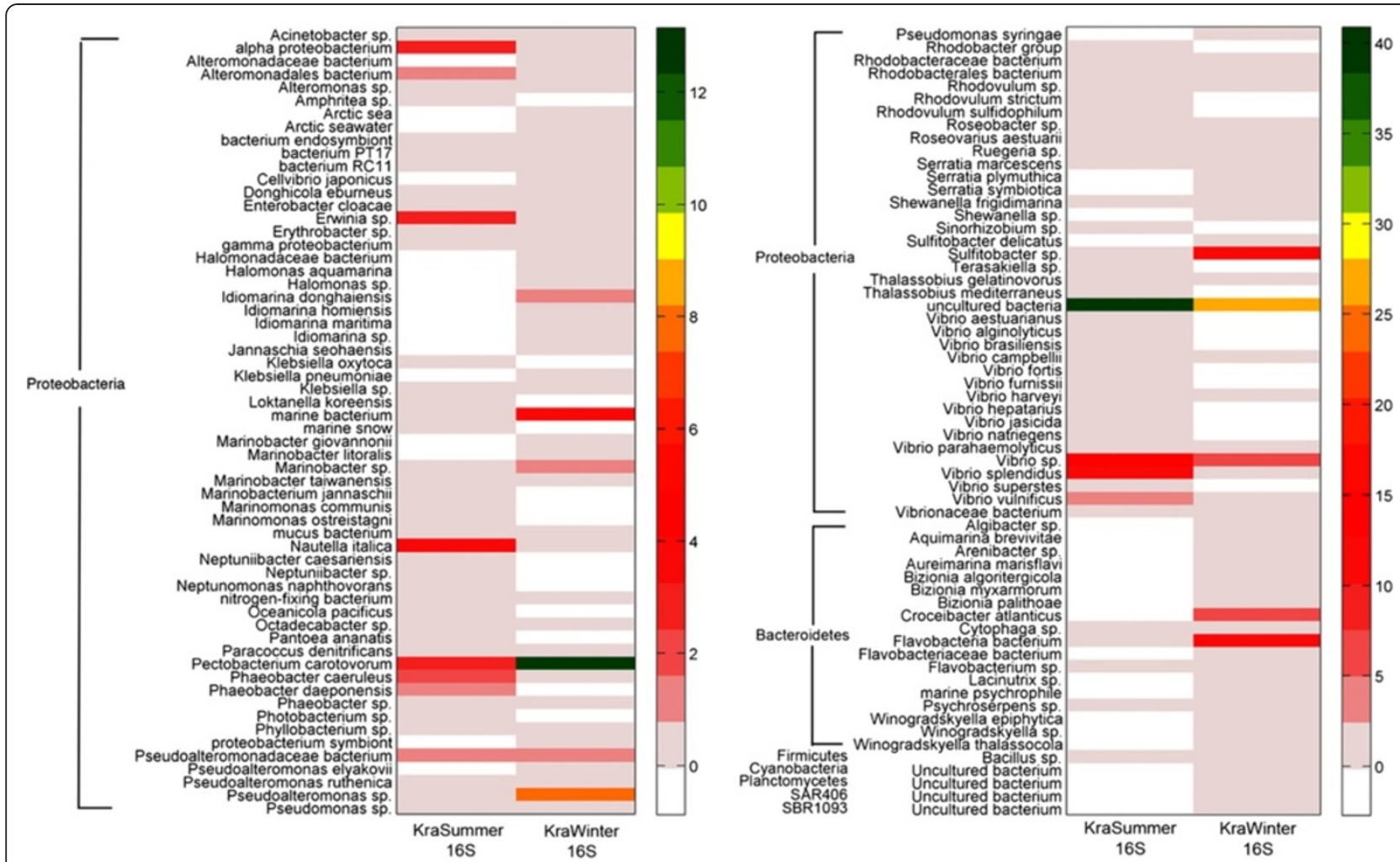

Figure 4 Frequency diagram of free-living prokaryotic species in summer and winter seasons. A percent relative abundance of each species is represented in color gradient.

proteases (clustering-based subsystems); DNA uptake, competence (DNA metabolism); spore DNA protection (dormancy and sporulation); protein translocation across cytoplasmic membrane (membrane transport); lightharvesting complexes (photosynthesis); bacteriocins, ribosomally synthesized antibacterial peptides (virulence, diseases and defense) (Figure 6b).

\section{Global comparative analyses of prokaryotic profiles representing summer and winter Kra reef surface} against coastal Tha Wang and Tham Phang of Sichang island, $73 \mathrm{GOS}$ sites, and 4 Northern Line islands sites Similarity between pairs of prokaryotic community structures were determined by theta similarity coefficients Yue \& Clayton (Thetayc) and Smith (Thetan), using mothur $[34,35]$. These similarity coefficients were used for principle coordinate analysis (PCoA) and un-weighted pair group method with arithmetic mean clustering (UPGMA). Results indicated the prokaryotic communities between the summer and winter Kra reef surface were most closely related, followed by coastal Tha Wang and Tham Phang of Sichang island, GS039 (S3.343333, W101.373889, sample depth at $2 \mathrm{~m}$, water depth at $>4000 \mathrm{~m}$, Open Ocean site, Tropical South Pacific region from INTERNATIONAL), GS040 (S4.498889, W105.070000, sample depth at $2.2 \mathrm{~m}$, water depth at $>4000 \mathrm{~m}$, Open Ocean site, Tropical South
Pacific region from INTERNATIONAL), GS045 (S9.017500, W127.767222, sample depth at $1.7 \mathrm{~m}$, water depth at $>4000 \mathrm{~m}$, Open Ocean site, Tropical South Pacific region from INTERNATIONAL, location of 400 miles from F. Polynesia), respectively (Figure 7). Specifically, the similarity coefficients revealed that the winter prokaryotic community of the Kra reef surface was more closely related to those of Tha Wang (Thetayc summer = 0.963739, Thetayc winter $=0.987038$ ) and Tham Phang (summer $=0.973696$, winter $=0.98611$ ) than the summer. In contrast, the summer rather than the winter Kra reef surface prokaryotic community was more closely related to those of GS039 $($ summer $=1.000000$, winter $=0.998852)$, GS040 (summer $=1.000000$, winter $=0.999934)$ and GS045 (summer $=1.000000$, winter $=0.99961)$.

Figure 8 compared the prokaryotic phyla distributions among Kra reef surface, Sichang island coast and the three related GOS communities. The relatedness between the winter $\mathrm{Kra}$ and the coastal Sichang prokaryotic communities was associated by the great presentation of Proteobacteria and Bacteroidetes, and the shared presence of Cyanobacteria, Planctomycetes, SAR406 and SBR1093. The relatedness between the summer Kra and GS039, GS040 and GS045 prokaryotic communities involved the rather restraint phyla distribution of simply Proteobacteria and Bacteroidetes (Figure 8). Figure 8 also 

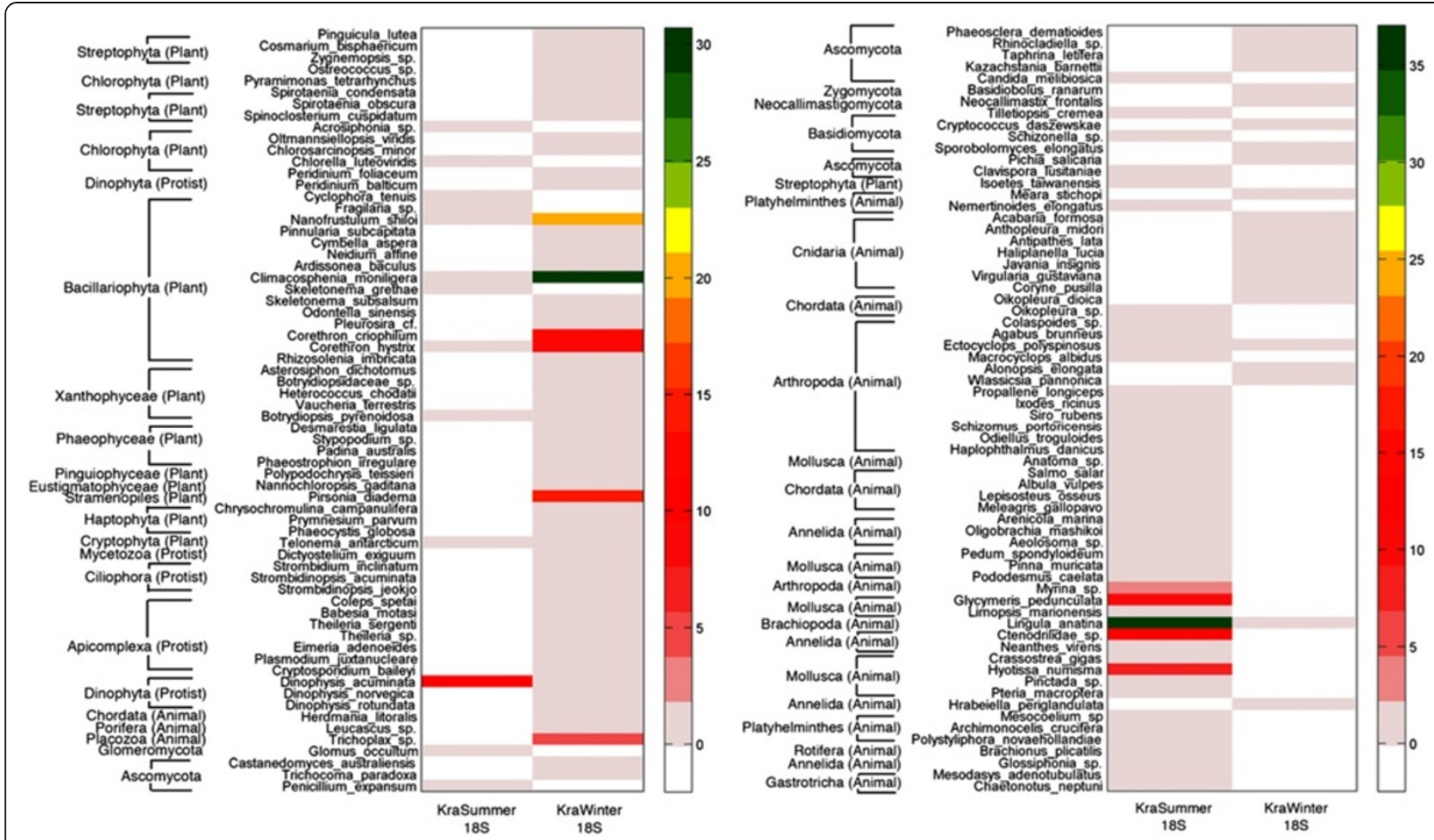

Figure 5 Frequency diagram of free-living small eukaryotic species in summer and winter seasons. Species and phyla are ordered according to their relative genetic distances among one another. A percent relative abundance of each species is represented in color gradient. In parenthesis represents a kingdom name to the phylum that belongs to the kingdom other than fungi.

revealed the more diversified prokaryotic phyla in Thai marine habitats: Tha Wang followed by Tham Phang, winter Kra reef surface, summer Kra reef surface, GS045, GS040 and GS039, respectively.

\section{Discussion}

To unravel the microbial biodiversity in the tropical reef surface of Kra island, a home of fruitful corals, and surrounding animals and plants, this present study was conducted to obtain the prokaryotic and eukaryotic databases for the summer and winter seasons of this coral reef surface. Free-living microorganisms and particles of approximately $0.22-30 \mu \mathrm{m}$ in diameter were captured, their metagenomes were extracted, and high number of reliable reads $(97.43 \%)$ and respectable read length (186 nt) were retrieved.

Total 16S and 18S rRNA gene analyses showed that bacteria the major domain of lives in this marine habitat (Figure 2), supporting the fact that bacteria are ubiquitous on almost every environment $[2,4]$. Meanwhile, archaea was not found in this marine habitat, consistent with current GOS analysis and previous literatures that reported 0 to $<1.0 \%$ archaea in typical marine microbial community $[2,9,17]$. Current GOS reported $0 \%$ archaea in estuary marine, $0.2 \%$ open-ocean, and $0.4 \%$ coastal water (average $0.3 \%$ for entire GOS) [2]. Wegley et al.
[17] reported $<1 \%$ archaea in coral fragments. As archaea should be more present in contaminated and polluted water environments $[2,4]$, the absence of archaea might in part highlight the cleanliness and non-polluted Kra coral reef water, allowing bacteria to be overpopulated.

As previous studies found that not only local environmental factors like sunlight, sea depth and substrate inclination but also seasons could exert a strong influence on the structural and functional biodiversity of coral benthic communities [36], our data demonstrated season could impact different microbial population structures and functions. The differences appeared since the domain and taxon distribution patterns (Figures 2 and 3). The greater bacterial proportion in the summer (Figure 3) was perhaps associated with its less abundant eukaryotes. The less animal disturbance due to time of dormancy and sporulation in the winter might support the growth of photosynthetic lives, and thus the biodiversity of eukaryotes in the winter.

For bacteria, the study found Proteobacteria to be predominant in the summer, while not only Proteobacteria but also Bacteroidetes were prevalent in the winter (Table 2A). Changing pattern of bacterial phyla composition was consistent with recent findings by Gilbert and colleagues $[9,10]$, stating microbial communities did change over time, between seasons, and between 


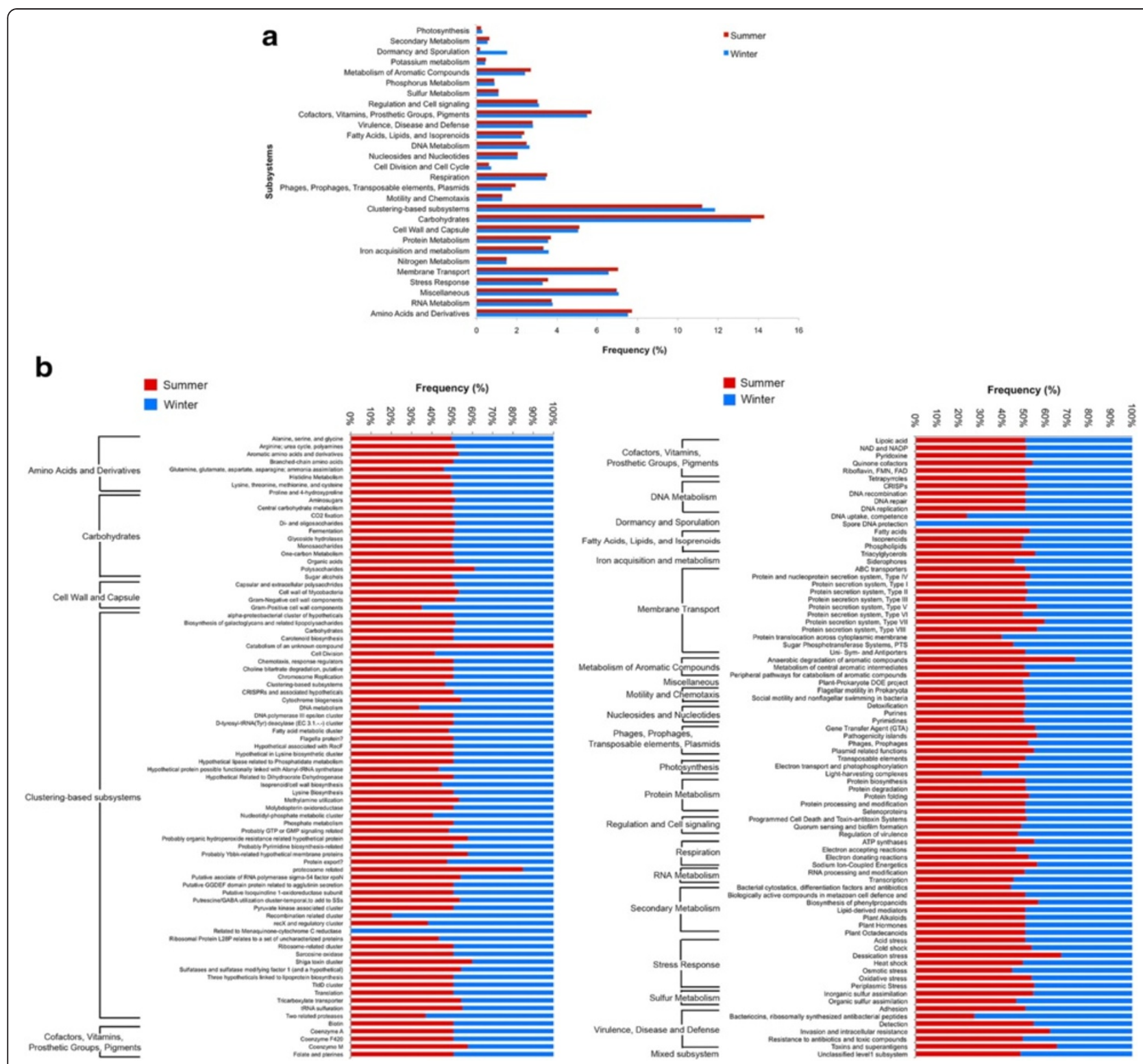

Figure 6 Metabolic potentials of bacteria communities in summer and winter Kra reef surface water. a, 28 major subsystems. $\mathbf{b}$, further subdivisions based on functional groups in each subsystem. Subsystems and functional groups are classified by mg-RAST [29,30,52].

day and night. In addition, the greater bacterial diversity in the winter (Figure 4) was consistent with these 6-year analyses of the bacterial structures, representing the coastal Western English Channel [9] and the coastal Plymouth in UK [10], that proved the bacterial diversity was highest in winter and at night, and showed season as one important factor for microbial diversity. Note these studies used the same experimental methods as ours. Furthermore, most bacterial phyla detected in the winter Kra reef surface were also found on the coral fragments from Bocas del Toro, Panama (N9.3306 W82.2494) (Proteobacteria 68\%, Firmicutes 10\%, Cyanobacteria 7\% and Actinobacteria 6\%) [17]. Note this study was, again, conducted using the same method as ours, and the different bacterial compositions between this and ours could be attributed to different marine geography and sampling time.

The prevalence of Bacteriodetes (Table 2B) in the winter Kra reef surface was not uncommon, as this phyla was also found in various marine environments [4,37]. Species in this phyla could serve marine lives pathogens and opportunistic human pathogens, for examples, Croceibacter atlanticus, Flavobacterium sp. and Psychroserpens sp. (Figure 4). C. atlanticus in a family Flavobacteriaceae was isolated from Bermuda Atlantic Ocean [38]. This species and other Flavobacterium sp. could cause fish 


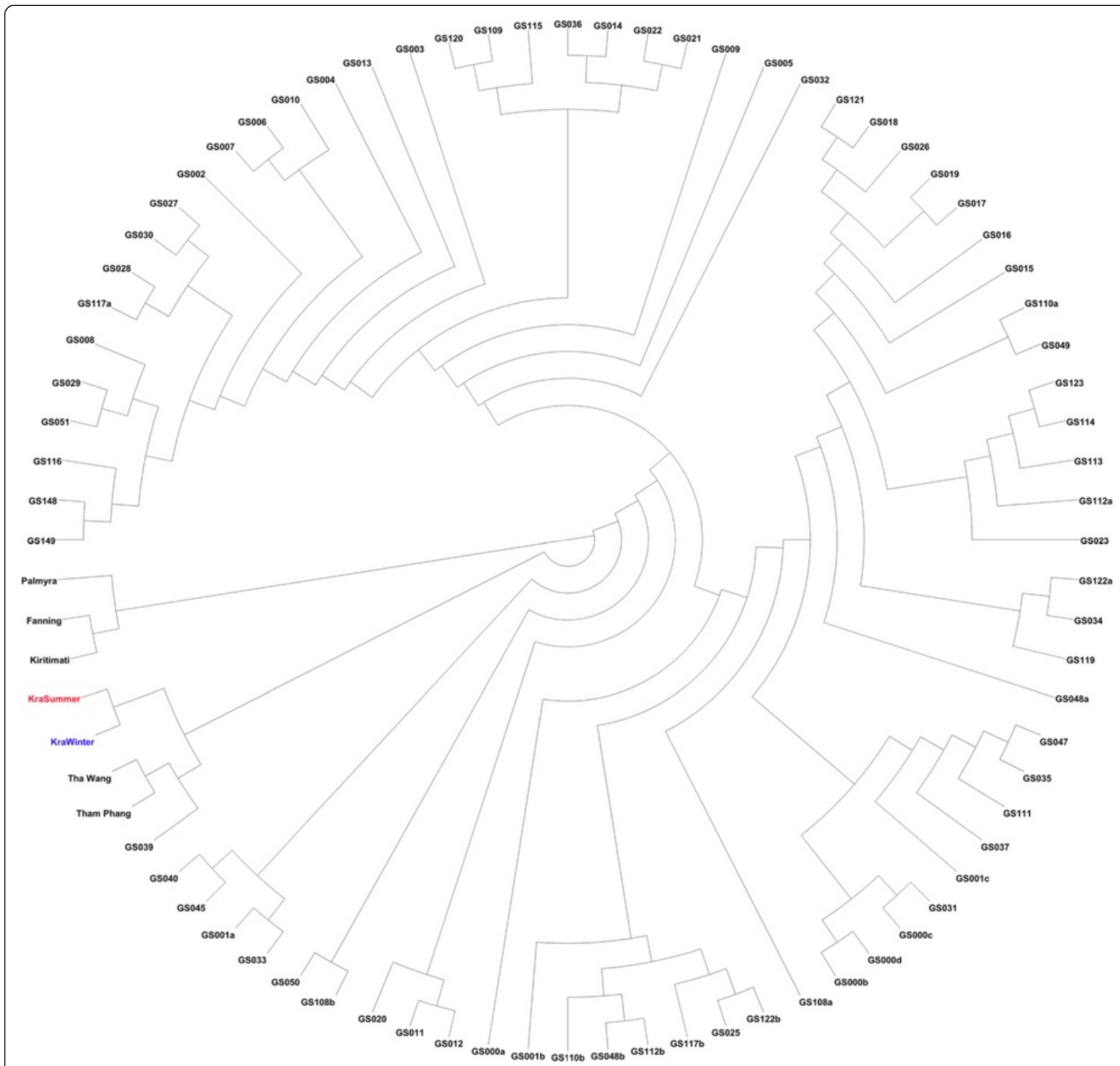

Figure 7 UPGMA tree showing distances of prokaryotic communities between Kra island reef surface, Sichang coast, 73 GOS sites and 4 Northern Line Islands sites. Distances between pairs of communities were based on similarity coefficients Thetayc computed by mothur [35].

diseases and are opportunistic pathogens for humans due to, for instance, their chorismate biosynthesis pathway [39]. Psychroserpens sp. is also in a family Flavobacteriaceae, and was found strictly associated with some fish diseases, such as amoebic gill disease [40]. Yet, bacterial pathogens were also noticed in the summer. Vibrio sp. (13.42\% summer, $6.94 \%$ winter) and Pectobacterium carotovorum (13.15\% summer, $2.86 \%$ winter) could cause diseases in marine animals and plants, respectively (Figure 4) [5,41]. Vibrio sp. in undercooked seafood serves as a frequent cause of foodborne diseases in humans [42].
Hence, summer and winter Kra reef surface contained species that might be pathogenic to marine lives and humans.

Additionally, the findings of SAR406 and SBR1093, which are relatives of green sulfur bacteria Chlorobium, in the winter (Figure 4), though supported the diversity peak in the winter, might pose a threat. The reason was because Chlorobium could live in harsh-living conditions and could out-compete the growth of other photosynthetic microbes in restricted nutrient condition. Chlorobium is a photolithotrophic oxidizer of sulfur, and could also produce huge quantities of methane and hydrogen sulfide, causing 


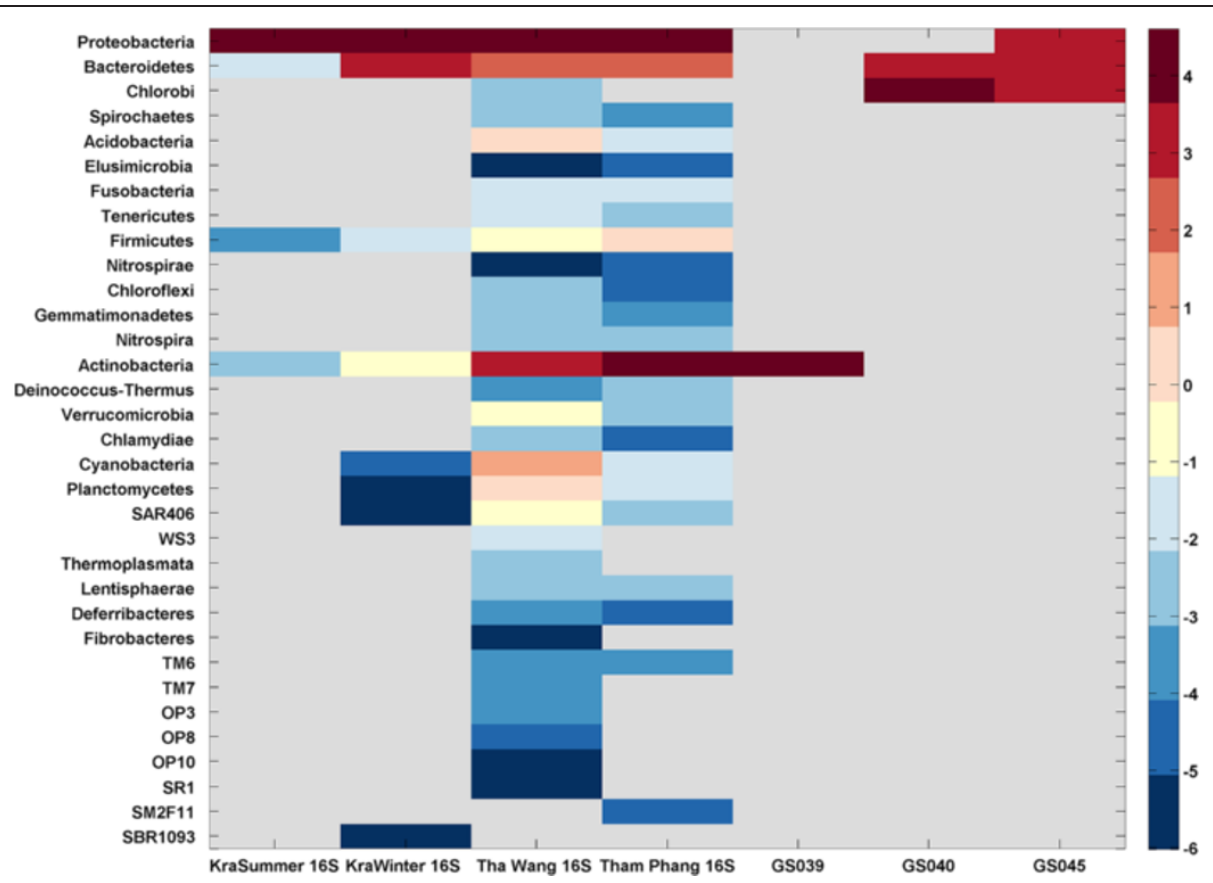

Figure 8 Frequency diagram comparing prokaryotic phyla compositions representing summer and winter Kra reef surface, Tha Wang and Tham Phang coasts of Sichang island, GS039, GS040 and GS045. Diagram was displayed in gradient colors. Phyla with red color convey that they were higher-represented when comparing with the average phyla compositions. Phyla with blue color mean that they were under-represented when comparing with the average phyla compositions. Grey color means no species present at that phylum.

global warming and acid rain [32]. In Thailand, Chlorobium was previously reported in a human-polluted Tha Wang coast of Sichang island [4]. Overall, the low Lennon and Yue \& Clayton theta similarity indices represented the dynamic of bacterial compositions between summer and winter seasons.

In support of the aforementioned results and previous reports $[9,10]$, the greatly diversified eukaryotic phyla and species, except for fungi, were found in the winter (Table 2B and Figure 5). Fungi were presented in a minor portion in both seasons, although their function could involve nutrient recycling like bacteria yet some could serve pathogens to the marine lives in the food webs [17]. Because several fungal species are not independent-living, the 2-step filtration method that selected for $\sim 0.22-30 \mu \mathrm{m} \mathrm{mi-}$ croorganisms or particles (extracellular DNAs) did not target these living-dependent fungi. However, the filtration method is widely practiced among metagenomic scientists $[1,2,22]$, serving as an appropriate method for collection of microbial-size organisms and particles in the seawater.

Plant species, mainly Climacosphenia moniligera from phylum Bacillariophyta (0.12\% summer vs. $30.70 \%$ winter: Figure 5), were abundant in the winter. These unicellular diatoms were found commonly along the corals, and could function as producer to this food chain [17]. Thus, the abundant plant species might infer the more productive coral ecosystem during the winter. On the other hand, the larger proportion of animal species in the summer
(Figure 5) could likely be extracellular DNA, as many detected animals were of larger size than $30 \mu \mathrm{m}$. A significant proportion of brachiopods Lingula anatina in the summer (37.07\% summer, 0.01\% winter; Figure 5) was questionable; perhaps marine animal activities were so high in the summer that their extracellular DNAs from larvae or any dead debris were detected [4]. The explicit differences in the 18S rRNA gene profiles between these seasons resulted in the very low Lennon and Yue \& Clayton theta similarity indices.

As coral microorganisms could help the coral animals to adjust to altering niches [15-17], the metabolic potentials for the summer and winter Kra reef surface bacterial communities were revealed to better understand this coral reef surface biodiversity pattern and its species-species interactions. 28 metabolic subsystems were discovered. Subsystems of carbohydrates, clustering-based subsystems, and amino acids and derivatives, were highly presented in both seasons, as these subsystems were important for any ecosystem. Finding of the greater dormancy and sporulation rate in the winter (Figure 6a) supported the general knowledge of this season for animal dormancy and sporulation. Functional groups of membrane transport and photosynthesis that were higher in the winter (Figure 6b) suggested the enriched food chain, supporting the diversity peak. These changes in key subsystems (i.e. photosynthesis) among seasons were consistent with previous studies by Gilbert et al. [9] and our water property measurements 
showing the greater percent dissolved oxygen and lower suspension solids in the winter (Table 1). Further, algae could stimulate bacterial respiration, and were found greater in the winter [43]. Consequently, changes in bacterial patterns between seasons have intricate relationships with other marine lives, and affect the metabolic potentials of the ecosystems potentially in a way characteristic to individual seasons.

Finally, the prokaryotic profiles representing Kra reef surface were compared to our Thai marine datasets, coastal Tha Wang and Tham Phang of Sichang island, 73 GOS and 4 Northern Line Islands datasets. The closer prokaryotic community structures between the Kra reef surface and the Sichang island (Figure 7) highlighted community relatedness due to oceanographic position (tropical climate). The next close community structures GS039, GS040 and GS045 were also probable, since these three sites represent open ocean Tropical South Pacific at coordinates S3.343333 W101.373889 (temperature $\left.28.6^{\circ} \mathrm{C}\right), \mathrm{S} 4.498889 \mathrm{~W} 105.070000\left(27.8^{\circ} \mathrm{C}\right)$, and S9.017500 W127.767222 $\left(28.3^{\circ} \mathrm{C}\right.$ ), respectively (Figure 9) [37]. These oceanographies shared relatively warm temperature of above $25^{\circ} \mathrm{C}$. The great prokaryotic diversity of Sichang islands, and also the Kra reef surface although with the less degree (Figure 8), highlighted the rich microbial biodiversity in the Thai maritime zone.

The present study provided complete independent-living prokaryotic and eukaryotic profiles of $0.22-30 \mu \mathrm{m}$ of summer and winter Kra reef surface. Still, time series and rainy season analyses could be performed next to understand the seasonal pattern of the Kra reef surface community. Also, microbial communities of the corals and the coral sediments should be determined to gain complete understanding of the coral reef ecosystem at the Kra island.

\section{Conclusions}

Summer and winter showed differences in species richness and evenness in Kra reef surface prokaryotic and small eukaryotic populations. The $16 \mathrm{~S}$ and $18 \mathrm{~S}$ rRNA gene databases serve as the baseline for future studies of coral reef microbes in Thai maritime, helping to elucidate association of microbes in differing oceanography and human impacts. Additionally, the data helped understand how Kra reef surface microbial community and metabolic potentials are associated with seasons and those of the other marine ecosystems worldwide.

\section{Methods}

\section{Reef surface water sampling}

Reef surface water samples ( $<1$ meter depth) around Kra island coral reefs were collected into separated sterile containers in May 2011 and in January 2012, between 11:00-14:00 hrs. Kra island is very small and comprises three small islets (Kra Yai, Kra Klang and Kra Lek), so simultaneously three independent water samples were collected around these islets per time period to represent the site. The sampling positions were at N8.40116 E100.73232, N8.39768 E100.73643 and N8.36135 E100.73524, and more than replicate samples were collected per sample position, per time. Sample collection site and positions were selected with support from Marine and Coastal Resources Center, Lower Gulf of Thailand. This research area did not require any permission or ethical approval to work on the coral

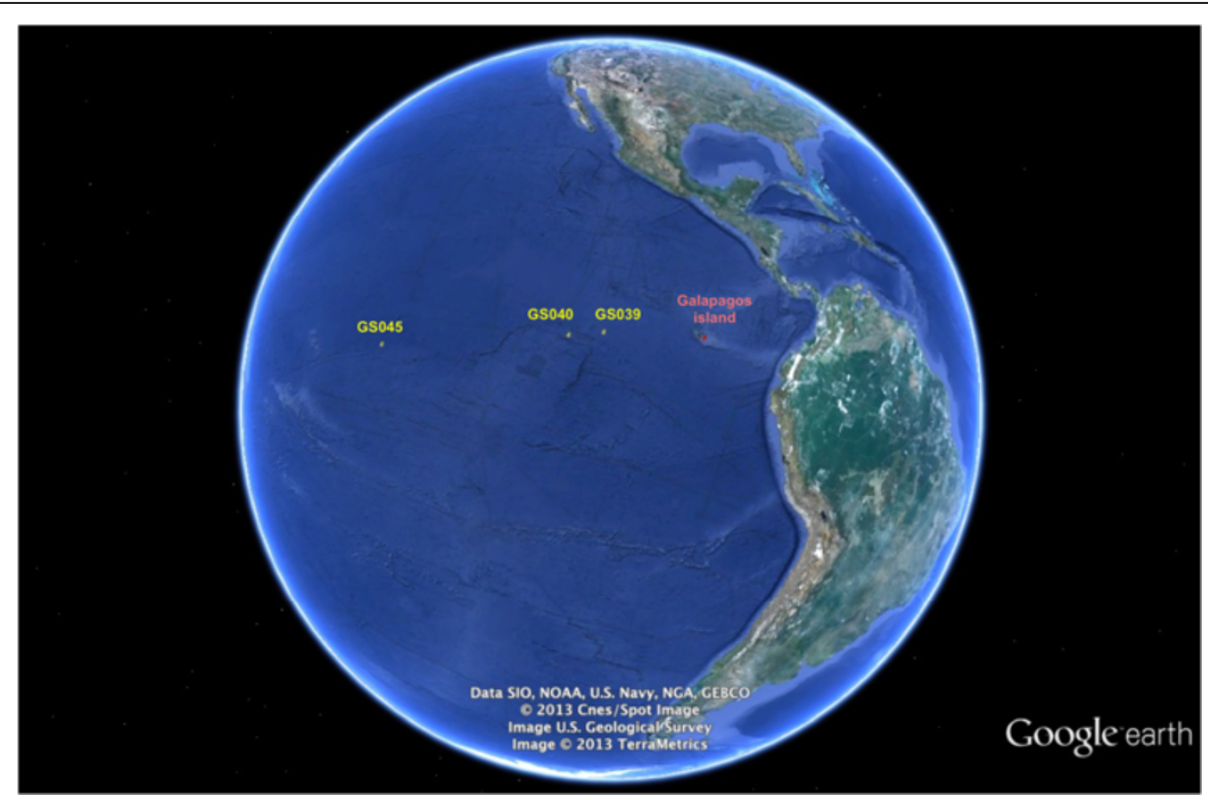

Figure 9 Satellite map of GS039, GS040 and GS045. The map was taken from Google Satellite Map, on 21 May 2013. 
reef. General water characteristics measured on-site included $\mathrm{pH}$, salinity (parts per thousand: ppt), temperature, dissolved oxygen and suspension solids. All samples were transported on ice, stored in $4^{\circ} \mathrm{C}$ and were processed for the next steps within 14 days.

\section{Metagenomic extraction and DNA quality examination}

The metagenomic DNA extraction was performed separately for each of the three oceanographic positions representative to the Kra island. Each water sample was poured through four-layered sterile cheesecloth to remove debris and large-size organisms of $>30 \mu \mathrm{m}$ [4]. Then, independent-living prokaryotes and eukaryotes and particles of sizes $\geq 0.2 \mu \mathrm{m}$ were captured using a sterile $0.22-\mu \mathrm{m}$ filter (Merck Millipore, Massachusetts, USA). Total nucleic acids were extracted, and appeared around $40 \mathrm{~kb}$ in size, according to Metagenomic DNA Isolation Kit for Water (Epicentre, Wisconsin, USA) [22]. The extracted metagenomes were analyzed for quality and concentration by agarose gel electrophoresis and $A_{260} / A_{280}$ nanodrop spectrophotometry.

\section{Pre-tagged 16S and 18S rRNA sequence libraries preparation and pyrosequeing}

The $16 \mathrm{~S}$ and $18 \mathrm{~S}$ rRNA gene library constructions were performed separately for each of the three oceanographic positions representative to the Kra island. For broad-range amplification of prokaryotic $16 \mathrm{~S}$ rRNA and $18 \mathrm{~S}$ rRNA genes, universal prokaryotic $338 \mathrm{~F}$ and $803 \mathrm{R}$ primers [4,44-46] and universal eukaryotic $1 \mathrm{~A}$ and 516R primers [4,47-49] were used. For sample labelling, 8-nt pyrotag sequences were added to each primers [50]. The primer sequences were listed in Additional file 3: Table S2. For each sample, a 50- $\mu$ l PCR reaction comprised $1 \times$ EmeraldAmp $^{\circ}$ GT PCR Master Mix (TaKaRa, Shiga, Japan), $0.3 \mu \mathrm{M}$ of each primer, and $100 \mathrm{ng}$ of the metagenome. The PCR conditions were $95^{\circ} \mathrm{C}$ for $4 \mathrm{~min}$, and 30-35 cycles of $94^{\circ} \mathrm{C}$ for $45 \mathrm{~s}, 50^{\circ} \mathrm{C}$ for $55 \mathrm{~s}$ and $72^{\circ} \mathrm{C}$ for $1 \mathrm{~min} 30 \mathrm{~s}$, followed by $72^{\circ} \mathrm{C}$ for $10 \mathrm{~min}$. PCR products of about 466 (16S rRNA) and 560 (18S rRNA) nucleotides in length were excised from agarose gels, and were purified using PureLink ${ }^{\odot}$ Quick Gel Extraction Kit (Invitrogen, New York, USA). To minimize stochastic PCR biases, two PCRs were performed per sample, and three samples were per season, yielding 6 PCR products to be pooled for pyrosequencing per sample period. $175 \mathrm{ng}$ each of the pyrotagged summer and winter $16 \mathrm{~S}$ rRNA gene amplicons and $50 \mathrm{ng}$ each of the pyrotagged summer and winter $18 \mathrm{~S}$ rRNA gene amplicons were pyrosequenced on an eight-lane Roche picotiter plate. In brief, the 454-sequencing adaptors were ligated to all $16 \mathrm{~S}$ and $18 \mathrm{~S}$ rRNA fragments. The reaction was purified by MinElute PCR Purification Kit (Qiagen), and pyrosequencing was performed using the 454 GS FLX system (Roche, Branford, CT) at the in-house facility of the
National Center for Genetic Engineering and Biotechnology, according to the recommendations of the supplier.

Sequence annotation and microbial composition analyses Sequences were categorized based on their appended pyrotag-sequences, and sequences of less than 50 nucleotides were removed. Sequences corresponding to summer and winter seasons were overviewed for domain and taxonomic abundances using mg-RAST [29,30] with default parameters. Species were annotated by BLASTN [31] with E-value $\leq 10^{-5}$, against $16 \mathrm{~S}$ rRNA gene databases including NCBI non-redundant [23], RDP [24] and Greengenes [25], and for $18 \mathrm{~S}$ rRNA genes the databases included NCBI nonredundant [23], EMBL [26,27] and SILVA [28]. Evolutionary distances and phylogenetic tree were computed with default thresholds (E-value $\leq 10^{-8}$, similarity score $\geq 80 \%$ ). Species (or phylum) percent relative abundance is the frequency of reads in the species (or phylum) divided by the total number of the identified reads. Similarity indices of taxonomic compositions between comparing communities were determined using Lennon and Yue \& Clayton similarity indices in mothur [31,51]. The data were also compared with those of the 73 GOS (https://portal.camera.calit2.net/gridsphere/ gridsphere) [1,3] and 4 sites of Northern Line Islands (Fanning, Kiritimati, Palmyra and Kingman) database [5], using Yue \& Clayton theta similarity coefficients (Thetayc) and Smith theta similarity coefficient (Thetan) in mothur $[34,35]$. The closer the similarity coefficient to 0.000 indicated the more similarity in community structures. PCoA was plotted in three-dimensions using mothur [35]. All 16S rRNA nucleotide sequences were aligned, and an un-weighted pair group method with arithmetic mean (UPGMA) clustering were constructed at distance of 0.20 using mothur [35]. The results were manually inspected to ensure properly sequence annotation, clustering, and phylogenetic tree relationship. Further, varied sequencing depths were analyzed by (i) random selections of equal number of reads between summer and winter, and examination of their taxonomic and phyla distribution patterns against those constructed by the entire datasets; and (ii) rarefaction curve of number of phyla on Y-axis against number of random reads on $\mathrm{X}$-axis.

\section{Bioinformatics for functional subsystem analyses}

Each bacterial species comprises own sets of metabolic and functional group potentials, and these information were available from mg-RAST server [30,52]. The $16 \mathrm{~S}$ rRNA gene profiles were thereby characterized into potential metabolic subsystems and functional groups based on their BLASTN species annotation [29].

\section{Availability of supporting data}

All nucleic acid sequences in this study were deposited in an open access repository named Sequence Read Archive 
(SRA) database of NCBI, accession number SRP041071 (http://trace.ncbi.nlm.nih.gov/Traces/sra/).

\section{Additional files}

Additional file 1: Figure S1. 165 and 185 rRNA genes overview for taxonomic compositions of normalized sequencing depth. Each season data comprised 10,000 and 1,600 random reads of 165 and $18 \mathrm{~S}$ rRNA sequences, respectively. Taxons with minor abundance were shown in corresponding colors but were not presented in the circular diagram.

Additional file 2: Table S1. Percent compositions of prokaryotic (A) and eukaryotic (B) phyla after pyrosequencing depths were normalized. Each identified read was classified in its corresponding phylum. The proportional percentage of each phylum was calculated by dividing the number of the identified reads in a phylum with the total number of the identified reads.

Additional file 3: Table S2. Pyrotagged 165 and $18 \mathrm{~S}$ rRNA gene primers. Italic sequence denotes 8-nt pyrotag sequence.

\section{Competing interests}

The authors declare that they have no competing interests.

\section{Authors' contributions}

NS conceived of the study, performed molecular biology experiments, participated in and coordinated the data analysis, drafted and revised the manuscript. AW performed data analysis. AA participated in study design. SM collected samples. SCT and DS carried out pyrosequencing. SDT participated in data analysis, and helped draft the manuscript. All authors read and approved the final manuscript.

\section{Acknowledgements}

The authors thank Khunaluck Kidmoa and Sarah Hof for laboratory support, and Doonyapong Wongsawaeng for manuscript editing. The authors also appreciate Marine and Coastal Resources Research Center, Lower Gulf of Thailand, Department of Marine and Coastal Resources. The research was supported by Thailand Research Fund MRG5480120, Research Fund from Faculty of Science, Chulalongkorn University, and Ratchadaphiseksomphot Fund, Chulalongkorn University. SDT acknowledges the Thailand Research Fund RSA5480026 and the "Research Chair Grant" of National Science and Technology Development Agency.

\section{Author details}

'Department of Microbiology, Faculty of Science, Chulalongkorn University, Bangkok 10330, Thailand. ${ }^{2}$ Genome Institute, National Center for Genetic Engineering and Biotechnology, Khlong Nueng, Khlong Luang, Pathum thani 12120, Thailand. ${ }^{3}$ Department of Pharmacology, Faculty of Pharmacy, Mahidol University, Bangkok 10400, Thailand. ${ }^{4}$ Department of Marine and Coastal Resources, Ministry of Natural Resources and Environment, Bangkok 10400, Thailand.

Received: 14 June 2013 Accepted: 30 May 2014

Published: 18 July 2014

\section{References}

1. Rusch DB, Halpern AL, Sutton G, Heidelberg KB, Williamson S, Yooseph S, Wu D, Eisen JA, Hoffman JM, Remington K, Beeson K, Tran B, Smith H, Baden-Tillson H, Stewart C, Thorpe J, Freeman J, Andrews-Pfannkoch C, Venter JE, Li K, Kravitz S, Heidelberg JF, Utterback T, Rogers Y-H, Falcón LI, Souza V, Bonilla-Rosso G, Eguiarte LE, Karl DM, Sathyendranath S, et al: The Sorcerer II global ocean sampling expedition: northwest Atlantic through eastern tropical Pacific. PLoS Biol 2007, 5:e77.

2. Biers EJ, Sun S, Howard EC: Prokaryotic genomes and diversity in surface ocean waters: interrogating the global ocean sampling metagenome. Appl Environ Microbiol 2009, 75:2221-2229.

3. Zinger L, Ammaral-Zettler LA, Fuhrman JA, Horner-Devine MC, Huse SM, Welch DBM, Martiny JBH, Sogin M, Bortius A, Ramette A: Global patterns of bacterial beta-diversity in seafloor and seawater ecosystems. PLoS One 2011, 6:e24570.
4. Somboonna N, Assawamakin A, Wilantho A, Tangphatsornruang S, Tongsima S: Metagenomic profiles of free-living archaea, bacteria and small eukaryotes in coastal areas of Sichang island, Thailand. BMC Genomics 2012, 13(Suppl7):S29. doi:10.1186/1471-2164-13-S7-S29.

5. Dinsdale EA, Pantos O, Smriga S, Edwards RA, Angly F, Wegley L, Hatay M, Hall D, Brown E, Haynes M, Krause L, Sala E, Sandin SA, Thurber RV, Willis BL, Azam F, Knowlton N, Rohwer F: Microbial ecology of four coral atolls in the Northern Line Islands. PLoS One 2008, 3:e1584.

6. Huang LN, Zhou H, Chen YQ, Luo S, Lan CY, Qu LH: Diversity and structure of the archaeal community in the leachate of a full-scale recirculating landfill as examined by direct $16 \mathrm{~S}$ rRNA gene sequence retrieval. FEMS Microbiol Lett 2002, 214:235-240.

7. Kendall MM, Liu Y, Sieprawska-Lupa M, Stetter KO, Whitman WB, Boone DR Methanococcus aeolicus sp. nov., a mesophilic, methanogenic aechaeon from shallow and deep marine sediments. Int/ J Syst Evol Microbiol 2006, 56:1525-1529.

8. Patil SA, Surakasi VP, Koul S, ljmulwar S, Vivek A, Shouche YS, Kapadnis BP: Electricity generation using chocolate industry wastewater and its treatment in activated sludge based microbial fuel cell and analysis of developed microbial community in the anode chamber. Bioresour Technol 2009, 100:5132-5139.

9. Gilbert JA, Field D, Swift P, Thomas S, Cummings D, Temperton B, Weynberg K, Huse S, Hughes M, Joint I, Somerfield PJ, Mühling M: The taxonomic and functional diversity of microbes at a temperate coastal site: a 'multi-omic' study of seasonal and diel temporal variation. PLoS One 2010, 5:e15545. doi:10.1371/journal.pone.0015545.

10. Gilbert JA, Steele JA, Caporaso JG, Steinbrück L, Reeder J, Temperton B, Huse S, McHardy AC, Knight R, Joint I, Somerfield P, Fuhrman JA, Field D: Defining seasonal marine microbial community dynamics. ISME J 2012, 6:298-308.

11. Spalding MD, Grenfell AM: New estimates of global and regional coral reef areas. Coral Reefs 1997, 16:225-230.

12. Bryant D, Burke L, McManus J, Spalding M: Reefs at risk: a map-based indicator of threats to the world's coral reefs. Cambridge: UNEP-WCMC; 1998.

13. Spalding MD, Green EP, Ravilious C: World atlas of coral reefs. California: University of California Press and UNEP/WCMC; 2001.

14. Burke L, Reytar K, Spalding M, Perry A: Reefs at risk revisited. World Resources Institute: Washington; 2011

15. Rohwer F, Seguritan V, Azam F, Knowlton N: Diversity and distribution of coral-associated bacteria. Mar Ecol Prog Ser 2002, 243:1-10.

16. Reshef L, Koren O, Loya Y, Zilber-Rosenberg I, Rosenberg E: The coral probiotic hypothesis. Environ Microbiol 2006, 8:2068-2073.

17. Wegley L, Edwawrds R, Rodriguez-Brito B, Liu H, Rohwer F: Metagenomic analysis of the microbial community associated with the coral Porites astreoides. Environ Microbiol 2007, 9:2707-2719.

18. Lins-de-Barros MM, Cardoso AM, Silveira CB, Lima JL, Clementino MM, Martins OB, Albano RM, Vieira RP: Microbial community compositional shifts in bleached colonies of the Brazilian reef-building coral Siderastrea stellata. Microb Ecol 2013, 65:205-213.

19. Vener JC, Remington K, Heidelberg JF, Halpern AL, Rusch D, Eisen JA, Wu D, Paulsen I, Nelson KE, Nelson W, Fouts DE, Levy S, Knap AH, Lomas MW, Nealson K, White O, Peterson J, Hoffman J, Parsons R, Baden-Tillson H, Pfannkoch C, Rogers Y-H, Smith HO: Environmental genome shotgun sequencing of the Sargasso Sea. Science 2004, 304:66-74.

20. Shaw AK, Halpern AL, Beeson K, Tran B, Venter JC, Martiny JBH: It's all relative: ranking the diversity of aquatic bacterial communities. EMI 2008, 10:2200-2210.

21. Yooseph S, Nealson KH, Rusch DB, McCrow JP, Dupont CL, Kim M, Johnson J, Montgomery R, Ferriera S, Beeson K, Williamson SJ, Tovchigrechko A, Allen AE, Zeigler LA, Sutton G, Eisenstadt E, Rogers Y-H, Friedman R, Frazier M, Venter JC: Genomic and functional adaptation in surface ocean planktonic prokaryotes. Nature 2010, 468:60-66.

22. Begum D, Murray J: Direct isolation of metagenomic DNA from environmental water samples. EPICENTRE forum 2008, 15:7-8.

23. Sayers EW, Barrett T, Benson DA, Bolton E, Bryant SH, Canese K, Chetvernin V, Church DM, DiCuccio M, Federhen S, Feolo M, Geer LY, Helmberg W, Kapustin Y, Landsman D, Lipman DJ, Lu Z, Madden TL, Madej T, Maglott DR, Marchler-Bauer A, Miller V, Mizrachi I, Ostell J, Panchenko A, Pruitt KD, Schuler GD, Sequeira E, Sherry ST, Shumway M, et al: Database resources of the National Center for Biotechnology Information. Nucleic Acids Res 2010, 38:D5-D16. 
24. Maidak BL, Cole JR, Liburn TG, Parker CT Jr, Saxman PR, Farris RJ, Garrity GM, Olsen GJ, Schmidt TM, Tiedje JM: The RDP-II (ribosomal database project). Nucleic Acids Res 2001, 29:173-174.

25. McDonald D, Price MN, Goodrich J, Nawrocki EP, DeSantis TZ, Probst A, Anderson GL, Knight R, Hugenholtz P: An improved Greengenes taxonomy with explicit ranks for ecological and evolutionary analyses of bacteria and archaea. ISME J 2011. doi:10.1038/ismej.2011.139.

26. Brunak S, Danchin A, Hattori M, Nakamura H, Shinozaki K, Matise T, Preuss D: Nucleotide sequence database policies. Science 2002, 298:1333.

27. Leinonen R, Akhtar R, Birney E, Bower L, Cerdeno-Tárraga A, Cheng Y, Cleland I, Faruque N, Goodgame N, Gibson R, Hoad G, Jang M, Pakseresht N, Plaister S, Radhakrishnan R, Reddy K, Sobhany S, Hoopen PT, Vaughan R, Zalunin V, Cochrane G: The European nucleotide archive. Nucleic Acids Res 2011, 39:D28-31.

28. Pruesse E, Quast C, Knittel K, Fuchs BM, Ludwig W, Peplies J, Glöckner FO: SILVA: a comprehensive online resource for quality checked and aligned ribosomal RNA sequence data compatible with ARB. Nucleic Acids Res 2007, 35:7188-7196.

29. Overbeek R, Begley T, Butler RM, Choudhuri JV, Chuang HY, Cohoon M, De Crécy-Laqard V, Diaz N, Disz T, Edwards R, Fonstein M, Frank ED, Gerdes S, Glass EM, Goesmann A, Hanson A, Iwata-Reuyl D, Jensen R, Jamshidi N, Krause L, Kubal M, Larsen N, Linke B, McHardy AC, Meyer F, Neuweger H, Olsen G, Olson R, Osterman A, Portnoy V, et al: The subsystems approach to genome annotation and its use in the project to annotate 1000 genomes. Nucleic Acids Res 2005, 33:5691-702.

30. Meyer F, Paarmann D, D'Souza M, Olson R, Glass EM, Kubal M, Paczian T, Rodriguez A, Stevens R, Wilke A, Wilkening J, Edwards RA: The metagenomics RAST server - a public resource for the automatic phylogenetic and functional analysis of metagenomes. BMC Bioinformatics 2008, 9:386. doi:10.1186/1471-2105-9-386

31. Altschul SF, Madden TL, Schäffer AA, Zhang J, Zhang Z, Miller W, Lipman DJ: Gapped BLAST and PSI-BLAST: a new generation of protein database search programs. Nucleic Acids Res 1997, 25:3389-3402.

32. Gordon DA, Giovannoni SJ: Detection of stratified microbial populations related to Chlorobium and Fibrobacter species in the Atlantic and Pacific oceans. Appl Environ Microbiol 1996, 62:1171-1177.

33. Björnsson L, Hugenholtz P, Tyson GW, Blackall LL: Filamentous Chloroflexi (green non-sulfur bacteria) are abundant in wastewater treatment processes with biological nutrient removal. Microbiol 2002, 8:2309-2318.

34. Yue JC, Clayton MK: A similarity measure based on species proportions. Commun Stat Theor Methods 2005, 34:2123-2131.

35. Schloss PD, Westcott SL, Ryabin T, Hall JR, Hartmann M, Hollister EB, Lesniewski RA, Oakley BB, Parks DH, Robinson CJ, Sahl JW, Stres B, Thallinger GG, Horn DJV, Weber CF: Introducing mothur: open-source, platform-independent, community-supported software for describing and comparing microbial communities. Appl Environ Microbiol 2009, 75:7537-7541.

36. Francini-Filho RB, Coni EO, Meirelles PM, Amado-Filho GM, Thompson FL, Pereira-Filho GH, Bastos AC, Abrantes DP, Ferreira CM, Gibran FZ, Güth AZ, Sumida PY, Oliveira NL, Kaufman L, Minte-Vera CV, Moura RL: Dynamics of coral reef benthic assemblages of the Abrolhos Bank, eastern Brazil: inferences on natural and anthropogenic drivers. PLOS One 2013. 8:e54260. doi:10.1371/journal.pone.0054260.

37. Marine ecological metagenomics. http://www.megx.net/metagenomes/ metagenomes.html.

38. Cho J-C, Giovannoni SJ: Croceibacter atlanticus gen. nov., sp. nov., a novel marine bacterium in the family Flavobacteriaceae. System Appl Microbiol 2003, 26:76-83.

39. BIOCYC database collection. http://biocyc.org/CATL216432/NEW-IMAGE? type=PATHWAY\&object=ARO-PWY.

40. Bowman JP, Nowak B: Salmonid gill bacteria and their relationship to amoebic gill disease. J Fish Dis 2004, 27:483-492.

41. Toth IK, Bell KS, Holeva MC, Birch PR: Soft rot erwiniae: from genes to genomes. Mol Plant Pathol 2003, 4:17-30.

42. Thompson FL, Gevers D, Thompson CC, Dawyndt P, Naser S, Hoste B, Munn $C B$, Swings J: Phylogeny and molecular identification of vibrios on the basis of multilocus sequence analysis. Appl Environ Microbiol 2005, 71:5107-5115

43. Barott KL, Rodriguez-Mueller B, Youle M, Marhaver KL, Vermeij MJ, Smith JE, Rohwer FL: Microbial to reef scale interactions between the reef-building coral Montastraea annularis and benthic algae. Proc Biol Sci 2012, 279:1655-1664.
44. Baker GC, Smith JJ, Cowan DA: Review and re-analysis of domain-specific 16S primers. J Microbiol Methods 2003, 55:541-555.

45. Humblot C, Guyoet J-P: Pyrosequencing of tagged 16S rRNA gene amplicons for rapid diciphering of the microbiomes of fermented foods such as pearl millet slurries. Appl Environ Microbiol 2009, 75:4354-4361.

46. Nossa CW, Oberdorf WE, Yang L, Aas JA, Paster BJ, DeSantis TZ, Brodie EL, Malamud D, Poles MA, Pei Z: Design of 16S rRNA gene primers for 454 pyrosequencing of the human foregut microbiome. WJG 2010, 16:4135-4144.

47. Diez B, Pedros-Alio C, Massana R: Study of genetic diversity of eukaryotic picoplankton in different oceanic regions by small-subunit rRNA gene cloning and sequencing. Appl Environ Microbiol 2001, 67:2932-2941.

48. Grant S, Grant WD, Cowan DA, Jones BE, Ma Y, Ventosa A, Heaphy S: Identification of eukaryotic open reading frames in metagenomic cDNA libraries made from environmental samples. Appl Environ Microbiol 2006, 72:135-143.

49. Bailly J, Fraissinet-Tachet L, Verner M-C, Debaud J-C, Lemaire M, Wésolowski-Louvel M, Marmeisse R: Soil eukaryotic functional diversity, a metatranscriptomic approach. ISME J 2007, 1:632-642.

50. Meyer M, Stenzel U, Hofreiter M: Parallel tagged sequencing on the 454 platform. Nat Protoc 2008, 3:267-278.

51. Chao A, Chazdon RL, Colwell RK, Shen T-J: Abundance-based similarity indices and their estimation when there are unseen species in samples. Biometrics 2006, 62:361-371.

52. Aziz RK, Bartels D, Best AA, Dejongh M, Disz T, Edwards RA, Formsma K, Gerdes S, Glass EM, Kubal M, Meyer F, Olsen GJ, Olson R, Osterman AL, Overbeek RA, McNeil LK, Paarmann D, Paczian T, Parrello B, Pusch GD, Reick C, Stevens R, Vassieva O, Vonstein V, Wike A, Zagnitko O: The RAST server: rapid annotations using subsystems technology. BMC Genomics 2008, 9:75. doi:10.1186/1471-2164-9-75.

doi:10.1186/1471-2164-15-607

Cite this article as: Somboonna et al: Structural and functional diversity of free-living microorganisms in reef surface, Kra island, Thailand. BMC Genomics 2014 15:607.

\section{Submit your next manuscript to BioMed Central and take full advantage of:}

- Convenient online submission

- Thorough peer review

- No space constraints or color figure charges

- Immediate publication on acceptance

- Inclusion in PubMed, CAS, Scopus and Google Scholar

- Research which is freely available for redistribution

Submit your manuscript at www.biomedcentral.com/submit
C) Biomed Central 